\title{
Redescription of Oecobius tadzbikus Andreeva et Tyshchenko, 1969 (Aranei: Oecobiidae)
}

\section{Переописание Oecobius tadzbikus Andreeva et Tyshchenko, 1969 (Aranei: Oecobiidae)}

\author{
Yuri M. Marusik ${ }^{1}$, Mikhail M. Omelko ${ }^{2,3}$, Seppo Koponen ${ }^{4}$ \\ Ю.М. Марусик ${ }^{1}$, М.М. Омелько ${ }^{2,3}$, С. Копонен ${ }^{4}$
}

\footnotetext{
${ }^{1}$ Institute for Biological Problems of the North of the Russian Academy of Sciences, Portovaya Str. 18, 685000 Magadan, Russia. E-mail: yurmar@mail.ru

${ }^{2}$ Far Eastern Federal University, Sukhanova Str., 8, Vladivostok 690950 Russia. Email: omelkom@gmail.com

${ }^{3}$ Gornotaezhnaya Station FEB RAS, Gornotaezhnoe Vil., Ussuriyski Dist., Primorski Krai 692533 Russia.

${ }^{4}$ Zoological Museum, University of Turku, FI-20014, Turku, Finland. E-mail: sepkopo@utu.fi

${ }^{1}$ Институт биологических проблем Севера ДВО РАН, Портовая 18, Магадан 685000, Россия.

2 Дальневосточный Федеральный университет, ул. Суханова 8, Владивосток, 690950, Россия.

${ }^{3}$ Горнотаёжная станция им. В.Л. Комарова ДВО РАН, с. Горнотаёжное, Уссурийский район, Приморский край 692533, Россия.
}

KEY WORDS: Araneae, spider, Oecobiinae, Central Asia, Tajikistan, endogyne.

КЛЮЧЕВЫЕ СЛОВА: Araneae, паук, Оеcobiinae, Средняя Азия, Таджикистан, эндогина.

ABSTRACT. In this paper we provide detailed redescription of Oecobius tadzhikus Andreeva et Tyshchenko, 1969 based on the types. Endogyne of this species is described for the first time.

РЕЗЮМЕ. Приводится детальное переописание Oecobius tadzhikus Andreeva et Tyshchenko, 1969 на основе типовой серии. Эндогина этого вида описана впервые.

\section{Introduction}

Oecobius Lukas, 1846, with 84 species [Platnick, 2014; World Spider Catalog, 2015], is the largest genus of the family (110 species). The genus is restricted to the Holarctic Region. Only four species are known outside this region (from India, Burkina Faso, Chad and Ghana), and all of them most likely do not belong to Oecobius. Oecobius is a rather poorly studied genus. There are only three revisional publications on this group, by Shear [1970], Shear \& Benoit [1974] and Wunderlich [1995] covering the Nearctic, Africa, and the Mediterranean region, respectively.

Twenty-eight species of Oecobius are known from a single sex: 16 from females and 12 from males [Platnick, 2014]. Half of the species are known from a single taxonomic record, and 20 species were addressed in two taxonomic publications connected to each other (same specimens were studied, or same figures were used) [Platnick, 2014].

More than half of Oecobius species occur in the Mediterranean, but the highest species diversity (34 species) was observed in the Canary Islands. Only three species of Oecobius are known to occur in Central Asia: O. nadiae (Spassky, 1936), O. przewalskyi Hu et Li, 1987, and O. tadzhikus Andreeva et Tyshchenko, 1969. Only the former species is well known; it is widespread in the region and was mentioned in several publications. Oecobius przewalskyi is known only from a type series of 5 females from the eastern part of the Xizang Province of China [Hu, 2001]. Oecobius tadzhikus is also known from its type series only, which was collected in the western Tajikistan. Although the latter species was addressed in two taxonomical publications, both were based on the same specimens and featured same figures. These published figures were very schematic and illustrated female habitus, epigyne and prolateral view of the male palp. Recently, we got an opportunity to examine the types of Oecobius tadzhikus and decided to redescribe it, since it is a poorly known species: the existing illustrations are schematic, and the description was published only in Russian.

\section{Methods}

The photographs were taken using an Olympus SZX16 stereomicroscope with an Olympus E-520 camera and prepared using CombineZP software at the Zoological Museum of the University of Turku. The species description format follows Shear [1970].

Abbreviations: ALE - anterior lateral eyes, AME anterior median eyes, PLE - posterior lateral eyes, PME - posterior median eyes. Leg articles: F femur, Mt - metatarsus, $\mathrm{Pt}$ - patella, T — tarsus, Ti tibia. All measurements are given in millimeters. 


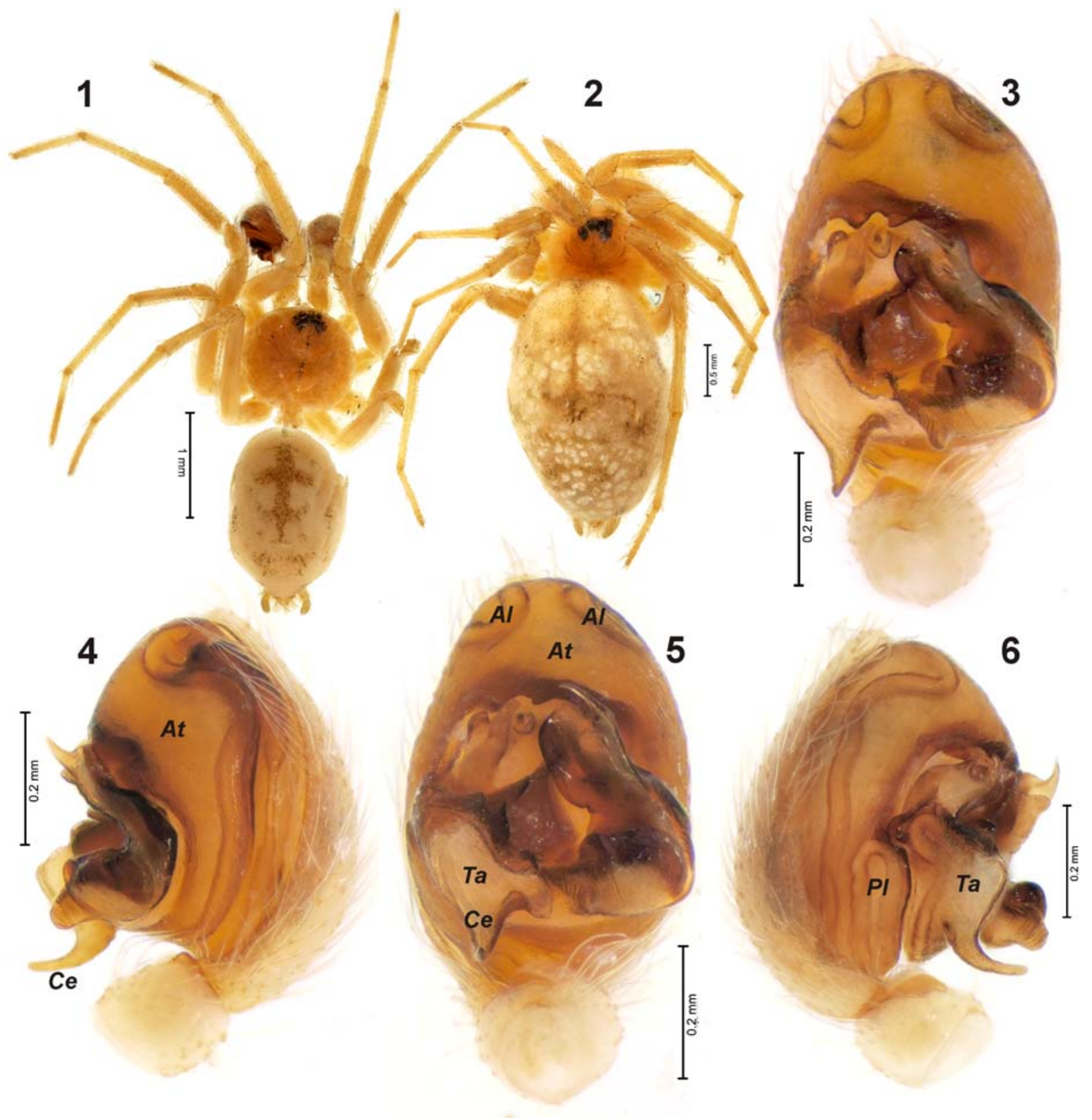

Figs 1-6. Habitus and male palp of Oecobius tadzhikus: 1 - habitus of male; 2 - habitus of female holotype; 3 - male palp, anteroventral; 4 - male palp, retrolateral; 5 - male palp, ventral; 6 - male palp, prolateral. Abbreviations: $A l$ - loop of the spermophor on anterior part of the tegulum; $\mathrm{At}$ - anterior part of the tegulum; $\mathrm{Ce}$ - claw like extension of $\mathrm{Ta} ; \mathrm{Pl}$ - loop of the spermophor on prolateral side of the tegulum; $T a$ - terminal apophysis.

Рис. 1-6. Габитус и пальпа Oecobius tadzhikus: 1 - габитус самца; 2 - габитус самки (голотип); 3 - пальпа самца, спередиснизу; 4 - пальпа самца, ретролатерально; 5 - пальпа самца, снизу; 6 - пальпа самца, пролатерально. Сокращения: $A l$ - петля семенного канальца в передней части тегулюма; $A t-$ передняя часть тегулюма; $\mathrm{Ce}$ - когтевидный вырост $\mathrm{Ta} ; \mathrm{Pl}-\mathrm{\text {петля }}$ семенного канальца на пролатеральной части тегулюма; $\mathrm{Ta}$ - терминальный отросток.

\section{Taxonomy}

Oecobius tadzhikus Andreeva et Tyshchenko, 1969 Figs 1-13.

O. t. Andreeva, Tyshchenko, 1969: 376, f. 3 ( ( $0^{7}+$ ).

O. $t .:$ Andreeva, 1976: 22 , f. 19-22 ( $\sigma^{2}+$, copy of figures from Andreeva \& Tyshchenko [1969]).
TYPES: Holotype $q$ and paratypes $10^{\top} 193$ juv., Tajikistan, Chiluchor-chashma, under stones on slope, 8.05.1965 (E. Martynova) from Zoological Institute, St. Petersburg (Russia), examined.

NOTE. Although holotype is mentioned in Andreeva \& Tyshchenko [1969], both females were found in one vial without a specification which of them is holotype. 

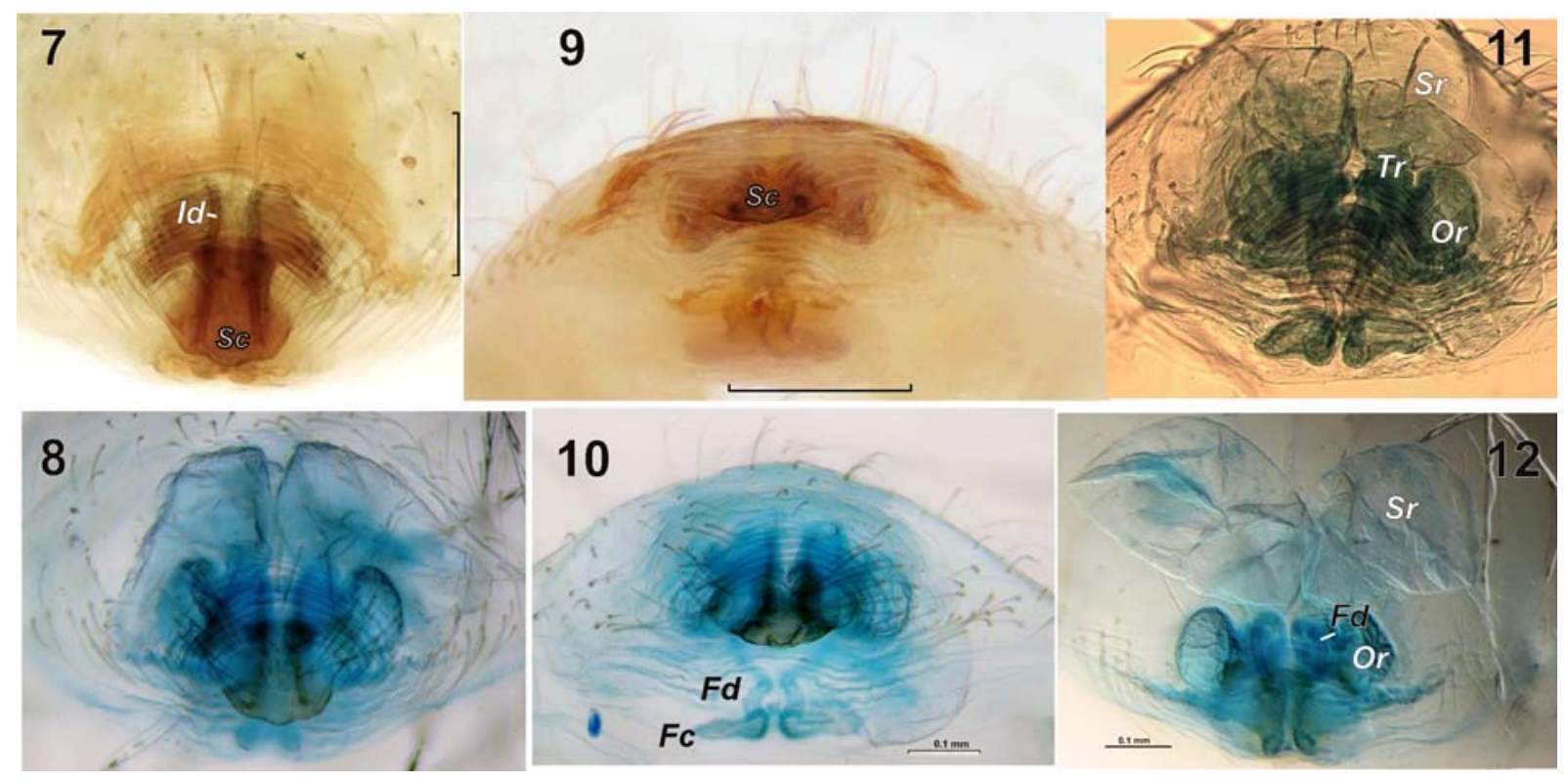

Figs 7-12. Epigyne of paratype female of Oecobius tadzhikus: 7-8 - ventral; 9-10 - posterior, 11 - dorsal; 12 - posterior-dorsal. Scale $=0.2 \mathrm{~mm}$ if not otherwise indicated. Abbreviations: $F c-$ fertilization chamber; $F d-$ fertilization duct; $I d-$ insemination duct; $\mathrm{Ok}$ - oval chamber of the receptacle; $\mathrm{Sc}$ - scape; $\mathrm{Sr}$ - sack-like chamber of the receptacle; $\mathrm{Tr}$ - tube-like part of the receptacle.

Рис. 7-12. Эпигина паратипа Oecobius tadzhikus: 7-8 - снизу; 9-10 - сзади, 11 - сверху; 12 - сзади-сверху. Масштаб 0,2 мм, если не указано иначе. Сокращения: $F c$ - оплодотворительная камера; $F d$ - оплодотворительный канал; $I d$ - копулятивный канал; $O k$ - овальная камера рецептакулы; $S c$ - скапус; $S r$ - мешковидная камера рецептакулы; $T r$ - трубковидная часть рецептакулы.

DIAGNOSIS. Male of Oecobius tadzhikus differs well from other Palaearctic congeners by a strongly developed anterior part of tegulum (At) being as large as the "embolic division" (much smaller in other species) and having a loop of spermophor on prolateral side, lacking in other congeners. Females differ from all other species occurring in Central Asia and Palaearctic by very large receptacles (Figs $8,11-12$ ) and transverse fertilization chambers ( $F c$, Figs $10-12$ ).

DESCRIPTION. Male. Total length 2.73. Carapace wider than long: 0.98 long, 1.13 wide; dirty brown without distinct pattern due to poor preservation (Fig. 1). According to original description, carapace had a brown spot. Sternum, maxillae, labium and clypeus yellow. Sternum outlined by a thin gray line. Clypeal projection evenly rounded. Carapace highest behind eye area. AME round, the largest in size, separated by a distance less than their single diameter. ALE small, adjoined with AME. PLE elongate, located close to AME. PME irregular, opalescent, separated a distance equal to their doubled diameter. Abdomen yellow with a longitudinal stripe crossed by two transverse stripes. Legs yellow without spots or rings.

Leg measurements in male/female: FI 0.93/1.13, FII 0.93/1.10, FIII 1.05/1.13, FIV 1.15/1.38, PtI 0.30/ 0.38 , PtII 0.38/0.40, PtIII 0.28/0.43, PtIV 0.30/0.43, TiI $0.83 / 0.78$, TiII $0.85 / 0.88$, TiIII $0.90 / 0.88$, TiIV 1.00/1.00, MtI 0.75/0.78, MtII 0.88/0.90, MtIII 0.95/ 1.00 , MtIV 1.13/1.13, TI 0.65/0.63, TII 0.73/0.70, TIII $0.65 / 0.65$, TIV $0.63 / 0.63$; total length: leg I $3.46 / 3.70$, leg II 3.77/3.98, leg III 3.83/4.09, leg IV 4.21/4.57.
Palp as in Figs 3-6, bulb as large as cymbium; tegulum with a very large anterior part $(A t)$; spermophor very long, encircling whole tegulum, and forming two circular loops (coils) on the anterior part of tegulum $(A l)$ and an elongated loop $(P l)$ in the prolateralbasal part of tegulum. Terminal apophysis $(T a)$ large, with square-like base and claw-like extension $(\mathrm{Ce})$.

Female (holotype). Total length 3.08. Carapace 1.0 long, 1.13 wide. Carapace dirty-brown without distinct pattern. Sternum, maxillae and labium yellow. Clypeal projection evenly rounded. Abdomen yellow with longitudinal stripe crossed by pair transverse stripes. ALE biggest, located close to AME. AME second in size, separated by a distance slightly less than their single diameter. PME much bigger than in males, irregular, opalescent, separated from each other a distance equal to their diameter. PLE small, located close both to PLE and AME. Carapace with a large round spot at the anterior part. Clypeus with a pair of black dots. Sternum, maxillae and labium yellow. Sternum outlined by a thin gray line like in males. Dorsal side of abdomen light brown, covered by white spots, with a dark longitudinal stripe in anterior part. Ventral side without white spots. Legs yellow. Tibia with poorly visible spots at ventral sides.

Epigyne as in Figs 7-9, with a kind of scape $(S c)$. Ventral and posterior part of epigynal plate with transverse wrinkles. Insemination ducts (Id) long, connected to a complex receptacle composed of three parts: oval chambers $(O r)$, wide tube-like part $(T r)$ and weakly sclerotized large sack part $(\mathrm{Sr})$. Sack part connected 


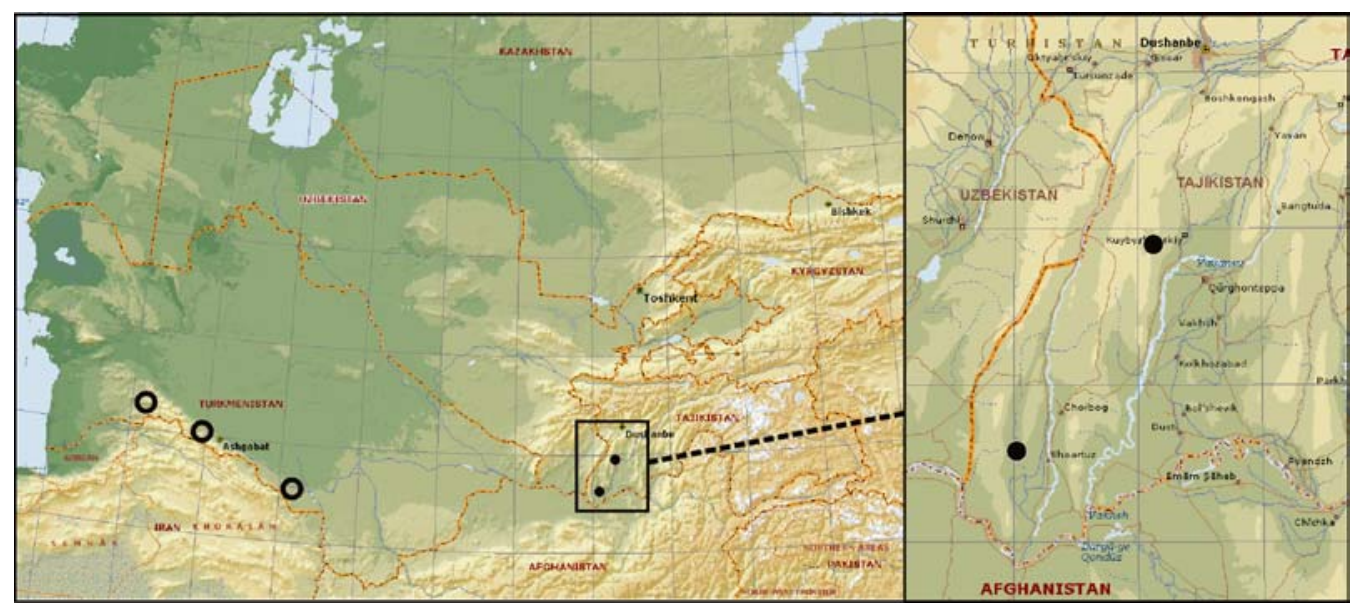

Fig. 13. Distribution records of Oecobius tadzhikus: Open circles refer to doubtful records from Turkmenistan.

Рис. 13. Распространение Oecobius tadzhikus: Незалитые кружки — сомнительные указания в Туркмении.

with fertilization chamber $\left(F_{c}\right)$ by a long duct $(F d)$. Fertilization chamber transverse.

COMMENTS ON POSITION OF THE SPECIES. Since Oecobius tadzhikus has a rather unusual epigyne (large receptacles, transverse fertilization chambers) and male palp (a very long spermophor forming several loops unknown in other congeners), it can very likely belong to a different genus.

DISTRIBUTION. Besides Tajikistan, Oecobius tadzhikus was reported also from the western Turkmenistan [Mikhailov, Fet, 1994], but these records could refer to another species (V. Fet, pers. comm.).

ACKNOWLEDGEMENTS. The English of an earlier draft was kindly checked by Victor Fet (Huntington, USA).

\section{References}

Andreeva E.M., Tyshchenko V.P. 1969. [On the fauna of spiders (Araneae) from Tadjikistan. Haplogynae, Cribellatae, Ecribellatae Trionychae (Pholcidae, Palpimanidae, Hersiliidae, Oxyopidae)] // Entomologicheskoe Obozrenie. Vol.48. No.2. P.373384 [in Russian].

Andreeva E.M. 1976. [Spiders of Tajikistan]. Dushanbe. 196 p. [in Russian]
Hu J.L. 2001. [Spiders in Qinghai-Tibet Plateau of China]. Henan Science and Technology Publishing House. 658 pp. [in Chinese].

Mikhailov K.G. 2013. The spiders (Arachnida: Aranei) of Russia and adjacent countries: a non-annotated checklist // Arthropoda Selecta. Supplement 3. 262 pp.

Mikhailov K.G., Fet V. 1994. Fauna and zoogeography of spiders (Aranei) of Turkmenistan // Fet V., Atamuradov K.I. (eds.). Biogeography and Ecology of Turkmenistan. Dordrecht: Kluwer Academic Publisher. P.499-524.

Platnick N.I. 2014. The World Spider Catalog. Version 15. American Museum of Natural History, New York. Available from: http://research.amnh.org/iz/spiders/catalog_15.0/index.html (accessed 28 March 2015).

Shear W.A. 1970. The spider family Oecobiidae in North America, Mexico, and the West Indies // Bulletin of the Museum of Comparative Zoology. No.140. P.129-164.

Shear W.A., Benoit P.L.G. 1974. New species and new records in the genus Oecobius Lucas from Africa and nearby islands (Araneae: Oecobiidae: Oecobiinae) // Revue Zoologique Africaine. T.88. P.706-720.

World Spider Catalog. 2015. Available from: http://wsc.nmbe.ch/ (accessed 28 March 2015).

Wunderlich J. 1995. Zu Taxonomie und Biogeographie der Arten der Gattung Oecobius Lucas 1846, mit Neubeschreibungen aus der Mediterraneis und von der Arabischen Halbinsel (Arachnida: Araneae: Oecobiidae) // Beiträge zur Araneologie. Bd.4. S.585-608.

Responsible editor K.G. Mikhailov 